\title{
Glosa do UCHWAey SĄDU NAJWYŻSZEGo z 13 MAJA 2015 R., III CZP 19/15, LEX NR 1679823
}

Przedstawiciel ustawowy małoletniego dziecka może udzielić pełnomocnictwa do złożenia oświadczenia o wyrażeniu zgody przewidzianej w art. 34 ust. 3 ustawy z dnia 5 grudnia 1996 r. o zawodach lekarza i lekarza dentysty (tekst jedn. Dz. U. z 2015 r. poz. 464).

Glosowana uchwała zapadła w związku z zagadnieniem prawnym przedstawionym przez Sąd Okręgowy, rozpatrujący w drugiej instancji sprawę o zezwolenie na zabieg medyczny. Wątpliwość Sądu Okręgowego dotyczyła możliwości skutecznego udzielenia przez rodzica w ramach wykonywania władzy rodzicielskiej pełnomocnictwa do wyrażenia zgody na dokonanie zabiegu medycznego u małoletniego dziecka.

Zagadnienie prawne, które legło o podstaw podjętej uchwały, zostało uzasadnione obszernie i wyczerpująco. Sąd Okręgowy, wychodząc od ogólnej definicji władzy rodzicielskiej i zasady osobistego jej wykonywania przez rodziców, poruszył wiele problemów związanych z przedmiotem uchwały. Przytoczenie licznych, spornych stanowisk doktryny związanych z rozważaną kwestią wskazuje na to, iż budzi ona niewątpliwie poważne wątpliwości i tym samym zasadnie zagadnienie prawne zostało przedstawione do rozstrzygnięcia Sądowi Najwyższemu¹.

Przedmiotem glosy będą nie tylko problemy poruszone w komentowanej uchwale, ale również te zagadnienia, które łączą się z nią bezpo-

* Dr, Katolicki Uniwersytet Lubelski Jana Pawła II; e-mail: agni285@wp.pl

${ }^{1}$ Nie sposób w ramach niniejszego opracowania odnieść się do wszystkich problemów poruszonych przez Sąd Okręgowy. Ze względu na treść komentowanej uchwały nie wydaje się to również celowe. 
średnio lub pośrednio. Rozważania im poświęcone wydają się bowiem niezbędne dla kompleksowego omówienia zagadnienia, będącego przedmiotem uchwały, a także - jak się wydaje - są niezbędne dla prawidłowego jej zastosowania. Glosowana uchwała ma bowiem, co należy podkreślić, niezwykle istotne znaczenie dla praktyki. Warto też zwrócić uwagę na to, że wzbudziła ona żywe zainteresowanie $\mathrm{w}$ doktrynie ${ }^{2}$. W dotychczasowych opracowaniach dotyczących przedmiotowego orzeczenia zostały poddane analizie przede wszystkim problemy, jakie rodzi przyjęte przez Sąd Najwyższy rozwiązanie z punktu widzenia prawa medycznego. Nie mniej interesujące i godne uwagi są jednak również skutki jakie pociąga ono za sobą na gruncie prawa rodzinnego.

W stanie faktycznym, leżącym u podstaw komentowanej uchwały Szpital Kliniczny wystąpił do Sądu Rejonowego na podstawie art. 34 ust. 3 ustawy o zawodach lekarza i lekarza dentysty ${ }^{3}$ o wyrażenie zgody na udzielenie małoletniej pacjentce świadczeń zdrowotnych. Małoletnia, która ma zespół Downa i jest upośledzona umysłowo w znacznym stopniu, mieszka w Domu Pomocy Społecznej. Jej matka nie żyje, a ojciec, któremu przysługuje pełna władza rodzicielska udzielił bratu matki, radcy prawnemu „,pełnomocnictwa upoważniającego do reprezentowania go przed wszelkimi instytucjami, szpitalami, urzędami i organami administracji oraz sądami, w tym przed Sądem Najwyższym, we wszystkich sprawach związanych z wykonywaną władzą rodzicielską"4. Pełnomocnik udzielił zgody na potrzebne małoletniej badania laboratoryjne i gastroskopię w znieczuleniu ogólnym, jednak wątpliwość budziła skuteczność tej zgody. Chociaż w przedmiotowej sprawie - na co zwrócił uwagę Sąd Najwyższy - zostało udzielone pełnomocnictwo ogólne upoważniające umocowanego do reprezentowania rodzica we wszystkich sprawach związanych z wykonywaniem władzy rodzicielskiej, wątpliwość

${ }^{2}$ Zob.: B. Janiszewska, Petnomocnictwo do wyrażenia zgody na udzielenie świadczenia zdrowotnego, "Monitor Prawniczy” 2015, nr 15, s. 819-821; taż, O udzieleniu pełnomocnictwa medycznego - uwagi na tle uchwaty III CZP 19/15, „Monitor Prawniczy” 2015, nr 19, s. 10431049; T. Zimna, Glosa do uchwaty SN z dnia 13 maja 2015 r., III CZP 19/15, System Informacji Prawnej LEX.

${ }^{3}$ Ustawa z dnia 5 grudnia 1996 r. o zawodach lekarza i lekarza dentysty; Dz. U. z 2017 r. poz. 125.

4 Tekst zagadnienia prawnego $\mathrm{z}$ uzasadnieniem zob.: http://www.sn.pl/ sprawy/SiteAssets/Lists/Zagadnienia_prawne/EditForm/III-CZP-0019_15_p.pdf [dostęp: 10.10.2015 r.]. 
Sądu Okręgowego dotyczyła dopuszczalności udzielenia przez rodzica pełnomocnictwa rodzajowego do wyrażenia zgody na zabieg.

Teza glosowanej uchwały już na pierwszy rzut oka jest niezwykle interesująca. Pojawiają się w niej bowiem dwa, występujące w Kodeksie cywilnym ${ }^{5}$, sposoby działania $\mathrm{w}$ cudzym imieniu: przedstawicielstwo ustawowe i pełnomocnictwo. Uchwała dotyczy więc sytuacji wyjątkowej - możliwości umocowania do działania w cudzym imieniu opartego na oświadczeniu woli podmiotu, który sam jest upoważniony do działania w cudzym imieniu, tyle że na podstawie ustawy.

Przedstawicielstwo ustawowe rodziców wobec dziecka pozostającego pod ich władzą rodzicielską jest zasadą w świetle przepisów Kodeksu rodzinnego i opiekuńczego ${ }^{6}$. Podkreślenia wymaga ponadto, że $\mathrm{w}$ prawidłowo funkcjonującej rodzinie nie jest konieczne sprawowanie stałego nadzoru nad wykonywaniem przedstawicielstwa ustawowego ${ }^{7}$. Takie rozwiązanie jest wynikiem założenia przez ustawodawcę dążenia rodziców do najpełniejszego realizowania dobra dziecka ${ }^{8}$. Reprezentacja ustawowa dziecka jest, obok pieczy nad osobą dziecka i zarządu majątkiem dziecka,jednymzelementów składającychsięnatreśćwładzy rodzicielskiej9 Jak jednak słusznie podkreśla się $\mathrm{w}$ doktrynie, granice pomiędzy tymi składnikami nie są ostre i nieraz wzajemnie na siebie nachodzą ${ }^{10}$. Co ważne w szczególności czynności z zakresu reprezentacji dziecka są bądź aktami zarządu jego majątkiem, bądź aktami pieczy nad osobą dziecka ${ }^{11}$. T. Smyczyński zauważa nawet, że reprezentacja dziecka, przyjmowana na ogół jako trzeci człon władzy rodzicielskiej, jest przyznana rodzicom jako

${ }^{5}$ Ustawa z dnia 23 kwietnia 1964 r. - Kodeks cywilny; Dz. U. z 2017 r. poz. 459.

${ }^{6}$ Ustawa z dnia 25 lutego 1964 r. - Kodeks rodzinny i opiekuńczy; Dz. U. z 2017 r. poz. 682 .

7 J. Misztal-Konecka, Wyłaczenie reprezentacji rodziców wobec dziecka pozostającego pod ich władza rodzicielska, „Przegląd Sądowy” 2010, nr 6, s. 69-70.

8 Tamże, s. 70. M. Świderska podkreśla w kontekście samej zgody na zabieg medyczny, że rodzice ze względu na ścisłe powiązania rodzinne i więź emocjonalną z małoletnim nie są poddawani tak restryktywnej kontroli jak opiekun (M. Świderska, Zgoda pacjenta na zabieg medyczny, Toruń 2007, s. 47).

${ }_{9}$ M. Andrzejewski, Prawo rodzinne i opiekuńcze, Warszawa 2010, s. 145; J. Ignatowicz, M. Nazar, Prawo rodzinne, Warszawa 2010, s. 313; J. Ignaczewski (aktualizacja K. Pudłowska), [w:] J. Ignaczewski (red.), Władza rodzicielska i kontakty z dzieckiem. Komentarz, Warszawa 2012, s. 93.

${ }^{10}$ J. Ignatowicz, M. Nazar, Prawo rodzinne, s. 313.

11 Tamże. 
instrument należytego wykonywania zadań rodzicielskich należących do zakresu pieczy nad osobą i nad majątkiem dziecka, gdyż bez niej rodzice nie byliby w stanie w ogóle wykonywać swoich obowiązków ${ }^{12}$. Podobnie J. Strzebinczyk, podkreślając służebną rolę tego atrybutu wobec pozostałych elementów treści władzy rodzicielskiej, wskazuje, że przedstawicielstwo jest techniczno - prawnym instrumentem, bez którego wykonywanie władzy rodzicielskiej byłoby niekiedy w ogóle niemożliwe ${ }^{13}$.

Ten niejako subsydiarny charakter reprezentacji dziecka jest szczególnie widoczny w kontekście udzielenia zgody na zabieg medyczny. Wyrażenie zgody na zabieg operacyjny jest wprost wskazywane jako przykład czynności z zakresu reprezentacji, odnoszącej się do osoby dziecka ${ }^{14}$. Troska o zdrowie dziecka i związane $\mathrm{z}$ nią zapewnienie mu pielęgnacji i leczenia są zaś elementami pieczy nad osobą dziecka ${ }^{15}$. Wyrażenie zgody na zabieg medyczny, będąc aktem reprezentacji dziecka, jest niewątpliwie również wyrazem dbałości o jego zdrowie, czyli wchodzi również w zakres pieczy nad osobą dziecka. T. Smyczyński wymienia zgodę rodziców w sprawie badań lekarskich, zabiegu, leczenia w odniesieniu do dziecka małoletniego do działań rodziców z zakresu władzy rodzicielskiej, kształtujących sytuację prawną dziecka i rozpatruje ją wśród elementów szczegółowych pieczy nad osobą dziecka ${ }^{16}$.

Za bezwzględnie niedopuszczalne Sąd Najwyższy uznał udzielenie przez rodzica pełnomocnictwa ogólnego do wykonywania wszystkich czynności z zakresu władzy rodzicielskiej. Taki zakaz nie budzi wątpliwości ${ }^{17}$. W pełni aprobując takie rozwiązanie należy podkreślić, że udzielenie pełnomocnictwa ogólnego do wykonywania wszystkich czynności z zakresu władzy rodzicielskiej skutkowałoby de facto przeniesieniem prerogatyw władzy rodzicielskiej na osobę trzecią i możliwością jej wykonywania przez tę osobę. Jak słusznie zaznaczył Sąd Najwyższy „umocowanie

12 T. Smyczyński, Prawo rodzinne i opiekuńcze, Warszawa 2009, s. 219.

13 J. Strzebinczyk, Prawo rodzinne, Warszawa 2013, s. 265.

14 J. Misztal-Konecka, Wyłaczenie reprezentacji, s. 70.

15 T. Smyczyński, Prawo rodzinne, s. 220.

16 Tamże, s. 221.

17 Podobnie, chociaż w kontekście możliwości ustanowienia pełnomocnikiem przedstawiciela ustawowego do reprezentowania osoby małoletniej, samego małoletniego, A. Sylwestrzak. Autorka podkreśla, że umocowanie obejmujące zbyt szeroki zakres czynności będzie nieważne i może stanowić podstawę do ingerencji sądu we władzę rodzicielską na podstawie art. 109 k.r.o. (A. Sylwestrzak, Małoletni petnomocnik, „Przegląd Sądowy” 2012, nr 7-8, s. 34). 
osoby trzeciej do pełnego wykonywania władzy rodzicielskiej mogłoby prowadzić w istocie do jej ograniczenia lub pozbawienia, co pozostaje w wyłącznej kognicji sądu opiekuńczego, a nadto jest sprzeczne z zasadą wyłączności i niepodzielności jej sprawowania"18. Na pozytywną ocenę zasługuje ponadto zwrócenie przez Sąd Najwyższy uwagi na art. 96 k.c. i podkreślenie, że jego treść wyklucza istnienie pełnomocnictwa o takim samym zakresie, jak przedstawicielstwa ustawowego.

Sąd Najwyższy, odnosząc się wprost do przedstawionego zagadnienia prawnego, opowiedział się natomiast za możliwością udzielenia przez przedstawiciela ustawowego małoletniego dziecka pełnomocnictwa do złożenia oświadczenia o wyrażeniu zgody na zabieg operacyjny albo zastosowanie metody leczenia lub diagnostyki, stwarzającej podwyższone ryzyko dla pacjenta. Uzasadnienie przyjętego przez Sąd Najwyższy stanowiska nie jest jednak bardzo rozbudowane i opiera się przede wszystkim na zasadzie dobra dziecka, jako podstawowym argumencie, potwierdzającym takie rozwiązanie.

Zgoda pacjenta musi spełniać szereg warunków koniecznych do uznania jej za prawnie ważną ${ }^{19}$. Do tych warunków należy udzielenie zgody przez osobę uprawnioną do jej udzielenia. Wyrażanie zgody przez osobę uprawnioną jest nawet traktowane jako podstawowy warunek skuteczności zgody ${ }^{20}$. Zatem udzielenie zgody przez osobę, która uprawnienia do jej wyrażenia nie posiada, nie będzie wywoływało skutków. W tym kontekście komentowana uchwała wydaje się być niezwykle ważna, nie tylko dla teoretycznych rozważań, związanych z istotą władzy rodzicielskiej $\mathrm{i}$ istotą przedstawicielstwa $\mathrm{w}$ ogóle i przedstawicielstwa ustawowego rodziców. Odpowiedź na pytanie o możliwość udzielenia przez rodzica pełnomocnictwa do wyrażenia zgody jest bowiem jednocześnie odpowiedzią na pytanie, czy zgoda pełnomocnika jest prawnie skuteczna.

18 Uzasadnienie uchwały SN z 13 maja 2015 r. III CZP 19/15.

19 Zob. np.: M. Filar, Postępowanie lecznicze (świadczenie zdrowotne) w stosunku do pacjenta niezdolnego do wyrażenia zgody, „Prawo i Medycyna” 2003, nr 13, s. 42; P. Dzienis, Zgoda pacjenta jako warunek skuteczności leczenia, „Przegląd Sądowy” 2001, nr 11-12, s. 81.

${ }^{20}$ R. Kędziora, Problematyka zgody pacjenta w świetle polskiego ustawodawstwa medycznego, „Prokuratura i Prawo” 2003, nr 7-8, s. 47. R. Kubiak podkreśla, że skuteczność zgody jest uzależniona od zrealizowania szeregu przesłanek i np. zgoda wyrażona przez osobę nieuprawnioną jest wadliwa i nie wywołuje skutków prawnych. Wyrażenie zgody przez pacjenta lub inny uprawniony podmiot autor traktuje jako wymóg podmiotowy zgody (R. Kubiak, Prawo medyczne, Warszawa 2014, s. 259). 
Uprawnienie pacjenta do wyrażenia zgody w przypadku, gdy on sam z pewnych przyczyn nie jest w stanie jej wyrazić, przechodzi na podmioty reprezentujące go, które decydują w zastępstwie pacjenta o mającym być przeprowadzonym zabiegu. Jest to tzw. zgoda zastępcza ${ }^{21}$. W przypadku pacjenta małoletniego lekarz może wykonać zabieg lub zastosować leczenie, o których stanowi art. 34 ust. 1 ustawy o zawodach lekarza i lekarz dentysty, po uzyskaniu zgody jego przedstawiciela ustawowego ${ }^{22}$. Podmiotem uprawnionym do wyrażenia zgody w przypadku osoby małoletniej będą więc najczęściej posiadający władzę rodzicielską rodzice i to właśnie władza rodzicielska przyznaje im prawo do podejmowania decyzji w zakresie zdrowia dziecka ${ }^{23}$.

Pewne niejasności w związku z tezą komentowanej uchwały pojawiają się w związku z regulacją art. 34 ust. 3 ustawy o zawodach lekarza i lekarza dentysty in fine. W przy padku gdy pacjent nie ma przedstawiciela lub gdy porozumienie się z nim jest niemożliwe, lekarz może wykonać czynności medyczne wskazane w art. 34 ust. 1 po uzyskaniu zezwolenia sądu opiekuńczego. Zasadne wydaje się w związku z tym pytanie o to, czy udzielenie przez przedstawiciela ustawowego małoletniego dziecka pełnomocnictwa do złożenia oświadczenia o wyrażeniu zgody nie jest próbą obejścia wymogu uzyskania zezwolenia sądu opiekuńczego. Sąd Najwyższy stwierdził w tym kontekście, że brak wskazania pełnomocnika jako osoby, która może udzielić zgody na zabieg, nie oznacza zakazu udzielenia pełnomocnictwa, gdyż jego wprowadzenie musiałoby mieć wyraźną podstawę ustawową. B. Janiszewska słusznie zauważa jednak, że Sąd Najwyższy wyeksponował argument o konieczności wyraźnej podstawy prawnej wyłączenia dopuszczalności ustanowienia pełnomocnika, nie rozważając w szerszym stopniu możliwości zaliczenia wyrażenia zgody na zabieg me-

${ }^{21}$ R. Kędziora, Problematyka zgody, s. 47.

${ }^{22}$ Na marginesie warto zauważyć, że problematyka przedmiotowej zgody rodziców jest poruszana $\mathrm{w}$ kontekście ochrony dóbr osobistych osób niemających pełnej zdolności do czynności prawnych (zwłaszcza małoletnich dzieci). A. Cisek zauważa, że niekiedy uniwersalny charakter ochrony dóbr osobistych bywa „w jakiejś mierze relatywizowany". Autor wskazuje, że możliwość uchylenia bezprawności naruszeń dóbr osobistych małoletniego dziecka była uzależniana od zgody, bądź jej braku, ze strony rodziców, przy jednoczesnym negowaniu własnych uprawnień dziecka w tym zakresie, a przejawem takiego sposobu rozumowania w ustawodawstwie jest np. wskazana zgoda (A. Cisek, Ochrona dóbr osobistych osób sprawujących funkcje publiczne, "Acta Universitatis Wratislaviensis", No 3161, Prawo CCCVIII, 2009, s. 32).

${ }^{23}$ K. Michałowska, Charakter prawny i znaczenie zgody pacjenta na zabieg medyczny, Warszawa 2014, s. 110. 
dyczny do drugiego z wyjątków z art. $95 \S 1$ k.c. ${ }^{24}$ Wynikająca bowiem z tego przepisu zasada dopuszczalności dokonywania czynności prawnych przez pełnomocnika nie ma charakteru absolutnego, a jej ograniczenia nie wynikają tylko z przepisu ustawy, ale mogą wynikać również z właściwości czynności prawnej ${ }^{25}$. M. Smyk, wśród czynności, których osobisty charakter wyłącza możliwość udzielenia pełnomocnictwa, nie wymienia czynności wchodzących w zakres władzy rodzicielskiej, w tym czynności z zakresu reprezentacji dziecka, chociaż na uwagę zasługuje fakt, że to instytucje prawa rodzinnego zajmują najwięcej miejsca $\mathrm{w}$ poświęconych temu zagadnieniu rozważaniom autora ${ }^{26}$. Podobnie W. Robaczyński za czynności, których właściwości przemawiają przeciwko możliwości ich dokonania przez przedstawiciela, uważa uznanie ojcostwa lub wyrażenie zgody na przysposobienie ${ }^{27}$, będące również instytucjami prawa rodzinnego. Zdaniem B. Janiszewskiej możliwość wyrażenia zgody na zabieg przez przedstawiciela ustawowego nie jest wystarczającym powodem, wbrew twierdzeniu Sądu Najwyższego, dla uznania, że czynność ta nie ma charakteru osobistego. Autorka dogłębnie uzasadniła swoje stanowisko, przytaczając wiele argumentów, przemawiających za zaliczeniem zgody do czynności osobistych ${ }^{28}$. Wydaje się jednak, że w związku z brakiem określenia przez ustawodawcę rozumienia pojęcia „właściwości czynności prawnej” możliwe byłoby przyjęcie życzliwej dla rodziców, udzielających pełnomocnictwa i, przede wszystkim dla dobra dziecka, wykładni tego pojęcia, pozwalającej na udzielenie pełnomocnictwa przez rodziców dziecka do wyrażenia zgody na zabieg medyczny ${ }^{29}$.

Istotne wątpliwości $\mathrm{w}$ przedmiotowej sprawie związane są ponadto z wymogiem, jaki stawia ustawodawca przed osoba, która ma pełnić funkcję pełnomocnika. Okoliczność, że pełnomocnik jest ograniczony w zdolności do czynności prawnych nie ma bowiem wpływu na ważność

${ }^{24}$ B. Janiszewska, O udzieleniu petnomocnictwa, s. 1046.

25 M. Smyk, Petnomocnictwo według kodeksu cywilnego, Warszawa 2010, s. 256.

26 Tamże, s. 257-263.

${ }^{27}$ W. Robaczyński, Komentarz do art. 95 Kodeksu cywilnego, [w:] M. Pyziak-Szafnicka, P. Księżak (red.), Kodeks cywilny. Komentarz. Część ogólna, LEX 2014.

${ }_{28}$ Zbędne wydaje się w tym miejscu powtarzanie wywodów autorki w tym przedmiocie. Zob. B. Janiszewska, O udzieleniu petnomocnictwa, s. 1046-1047.

${ }^{29}$ Nie bez znaczenia jest $\mathrm{w}$ tym kontekście sformułowany przez M. Smyka postulat rezygnacji w art. $95 \S 1$ k.c. z pojęcia „właściwości czynności prawnej”, motywowany wątpliwościami, jakie wiążą się z uznaniem osobistego charakteru konkretnych czynności prawnych (M. Smyk, Petnomocnictwo, s. 257). 
czynności dokonanej przez niego w imieniu mocodawcy (art. 100 k.c.). Ustawodawca wyszedł tutaj z założenia, że stawianie wyższych wymagań co do zdolności do czynności prawnych pełnomocnika, tj. wymóg pełnej zdolności, nie jest konieczny, gdyż mocodawca sam wybiera sobie pełnomocnika. Jeżeli więc ma zaufanie do osoby, która nie posiada pełnej zdolności do czynności prawnych, nie należy ograniczać jego pola decyzyjnego w tym względzie ${ }^{30}$. Wymóg jedynie ograniczonej zdolności do czynności prawnych tłumaczy się również tym, że skutki działania pełnomocnika nie dotyczą jego, lecz reprezentowanego ${ }^{31}$. A. Sylwestrzak zauważa ponadto, że art. 100 k.c. nie zawiera "dosadnego stwierdzenia”, że pełnomocnikiem może być osoba mająca ograniczoną zdolność do czynności prawnych i „ustawodawca zdaje się tym samym nie zachęcać mocodawców do posługiwania się pełnomocnikami ograniczonymi w zdolności do czynności prawnych, choć godzi się tolerować fakt udzielenia umocowania takiej osobie, poprzez uchylenie negatywnych konsekwencji braku pełnej zdolności do czynności prawnych"32.

Problem ten związany jest bezpośrednio z zakresem zdolności do reprezentacji małoletniego pełnomocnika. Nabycie przez osobę ograniczoną w zdolności do czynności prawnych pełnej zdolności do reprezentacji, obejmującej również zdolność do dokonywania w roli pełnomocnika takich czynności, których we własnym imieniu osoba ta nie mogłaby samodzielnie dokonać, jest ogólną reguła, która wynika z art. 100 k.c. ${ }^{33}$ K. Kopaczyńska-Pieczniak zwraca jednak uwagę na to, że sytuacja, w której pełnomocnictwo jest udzielane osobie, która ma pełną zdolność do czynności prawnych, zachodzi najczęściej. Zdaniem autorki udzielenie pełnomocnictwa osobom o ograniczonej zdolności do czynności prawnych powinno, ze względu na interes mocodawcy, dotyczyć tylko tych czynności prawnych, których osoba taka może dokonać samodzielnie bez zgody przedstawiciela ustawowego ${ }^{34}$.

Stanowisko to pozostaje $\mathrm{w}$ pełni aktualne w kontekście pełnomocnictwa do wyrażenia zgody na zabieg medyczny. Osoba mająca ograniczo-

30 Z. Radwański, A. Olejniczak, Prawo cywilne - część ogólna, Warszawa 2015, s. 332.

31 A. Wolter, J. Ignatowicz, K. Stefaniuk, Prawo cywilne. Zarys części ogólnej, Warszawa 2001, s. 340.

32 A. Sylwestrzak, Małoletni, s. 28.

${ }^{33}$ Tamże, s. 31.

${ }^{34}$ K. Kopaczyńska-Pieczniak, [w:] A. Kidyba (red.), Kodeks cywilny. Komentarz LEX. Tom I. Część ogólna, Warszawa 2012, s. 622. 
ną zdolność do czynności prawnych nie może wyrazić takiej zgody samodzielnie. Trudno wyobrazić więc sobie sytuację, gdy taką zgodę wyraża pełnomocnik również niemający pełnej zdolności do czynności prawnych, tym bardziej że władza rodzicielska przysługuje tylko rodzicom, mającym pełną zdolność do czynności prawnych, a rodzice, którzy takiej zdolności nie maja uczestniczą jedynie w sprawowaniu bieżącej pieczy nad osobą dziecka i w jego wychowaniu, chyba że sąd opiekuńczy ze względu na dobro dziecka postanowi inaczej (art. $96 \S 2$ k.r.o.). Na tę kolizję zwrócił uwagę Sąd Okręgowy w uzasadnieniu zagadnienia prawnego, podkreślając, że umożliwienie działania pełnomocnikowi ograniczonemu w zdolności do czynności prawnych może doprowadzić do obejścia wymogu pełnej zdolności do czynności prawnych, która jest konieczna do wykonywania władzy rodzicielskiej.

Sąd Najwyższy nie odniósł się w podjętej uchwale do sygnalizowanej kwestii. Biorąc jednak pod uwagę jej brzmienie, należy stwierdzić, że zdaniem Sądu Najwyższego nie jest to wystarczający argument przeciwko możliwości udzielenia przez przedstawiciela ustawowego małoletniego dziecka pełnomocnictwa do złożenia oświadczenia o wyrażeniu zgody. Co jednak oczywiste, trudno wyobrazić sobie sytuację, w której rodzic udziela takiego pełnomocnictwa osobie np. 14-letniej czy ubezwłasnowolnionej częściowo. Wątpliwe jest w tym kontekście również przyjęcie możliwości udzielenia pełnomocnictwa do wyrażenia zgody przez rodzica, któremu przysługuje władza rodzicielska, drugiemu z rodziców, niemającemu pełnej zdolności do czynności prawnych ${ }^{35}$. Takie postępowanie chociaż formalnie zgodne $\mathrm{z}$ art. 100 k.c. - może być niewątpliwie oceniane z perspektywy prawidłowego wykonywania władzy rodzicielskiej jako mogące skutkować zagrożeniem dobra dziecka.

Zdecydowanie należy również wykluczyć możliwość udzielenia pełnomocnictwa przez rodzica samemu dziecku, którego miałaby dotyczyć zgoda. Takie działanie w swej istocie godziłoby w cel instytucji zgody zastępczej. Warto zwrócić w tym miejscu uwagę na zdanie J. Haberko, która analizując, jak sama autorka podkreśla, specyficzny przypadek udzielenia pełnomocnictwa przez rodzica samemu dziecku, zwraca uwagę na to, że „istota czynności, jaką jest zgoda przedstawiciela ustawowego na dokonanie przez małoletniego czynności prawnej zobowiązującej lub rozporządzającej, jak również osobisty charakter tego oświadczenia i «zespolenie»

\footnotetext{
${ }^{35}$ Zob. art. $94 \S 1$ k.r.o.
} 
go z faktem przedstawicielstwa ustawowego, wyłącza dopuszczalność posłużenia się pełnomocnikiem $\mathrm{w}$ omawianym zakresie i skutecznie zamyka drogę udzielenia pełnomocnictwa nie tylko małoletniemu, ale komukolwiek" ${ }^{\prime \prime}$. Chociaż autorka, przeciwnie do stanowiska zajętego przez Sąd Najwyższy, pośrednio w ogóle wyklucza udzielenie pełnomocnictwa do wyrażenia zgody na zabieg medyczny, przywołane argumenty pozostają aktualne w kontekście wyłączenia możliwości udzielenia przez rodzica takiego pełnomocnictwa swemu dziecku.

Osoba, której rodzic udziela pełnomocnictwa do wyrażenia zgody powinna być osobą godną zaufania i odpowiedzialną. Na pozytywną ocenę będzie zasługiwało powierzenie funkcji pełnomocnika osobie, która utrzymuje kontakty z dzieckiem, znajdującej się w kręgu osób wymienionych $\mathrm{w}$ art. $113^{6}$ k.r.o., tj. rodzeństwu, dziadkom, powinowatym w linii prostej czy innym osobom, jeżeli sprawowały one przez dłuższy czas pieczę nad dzieckiem. Bliska relacja z dzieckiem powinna być gwarancją korzystania z pełnomocnictwa zgodnie z celem, w którym zostało ono udzielone, tj. zgodnie z dobrem dziecka. Niestety krytycznie ocenić należy brak odniesienia $\mathrm{w}$ uzasadnieniu uchwały do rozważanych powyżej zagadnień, szczególnie że Sąd Okręgowy zasygnalizował wskazane wątpliwości w zagadnieniu prawnym.

Komentowane orzeczenie nasuwa również szereg innych wątpliwości natury praktycznej, które nie zostały wprost rozstrzygnięte $\mathrm{w}$ jego treści. Sąd Najwyższy stwierdził w nim, że uprawnienie do udzielenia pełnomocnictwa do złożenia oświadczenia przysługuje przedstawicielowi ustawowemu małoletniego dziecka. W związku z tym rodzi się pytanie o to, czy jeżeli władza rodzicielska przysługuje obojgu rodzicom, to każdy z nich jest uprawniony do udzielenia takiego pełnomocnictwa. Za przyjęciem takiego rozwiązania przemawiałaby regulacja art. $98 \S 1 \mathrm{zd}$. 2 k.r.o., zgodnie z którą ,jeżeli dziecko pozostaje pod władzą rodzicielską obojga rodziców, każde $\mathrm{z}$ nich może działać samodzielnie jako przedstawiciel ustawowy dziecka". Z drugiej jednak strony należałoby zastanowić się nad tym, czy decyzja o udzieleniu pełnomocnictwa nie jest „istotną sprawą dziecka”, o której rodzice, zgodnie z art. 97 § 2 k.r.o. powinni rozstrzygać wspólnie. Pojęcie „istotnych spraw dziecka”, którym posłużył się tutaj ustawodawca, jest pojęciem nieostrym ${ }^{37}$. W doktrynie

${ }^{36}$ J. Haberko, Dziecko jako petnomocnik rodzica, "Przegląd Sądowy” 2013, nr 7-8, s. 62.

37 J. Słyk, Rozstrzyganie o istotnych sprawach dziecka w przypadku braku porozumienia rodziców, „Prawo w działaniu. Sprawy cywilne” 2013, nr 14, s. 78. 
wskazuje się, że decyzja dotycząca leczenia dziecka może być sprawą istotna, zależy to jednak od rodzaju choroby, stanu zdrowia dziecka, rozmiarów możliwych interwencji lekarza oraz mogących wystąpić skutków ${ }^{38}$.

Decyzja o udzieleniu pełnomocnictwa do wyrażenia zgody nie jest oczywiście decyzją dotyczącą leczenia dziecka, chociaż nie można zaprzeczyć, że udzielenie takiego pełnomocnictwa może w konsekwencji wpływać na sposób leczenia dziecka. Wydaje się, że w tym kontekście słuszne jest rozróżnienie podjęcia decyzji o udzieleniu pełnomocnictwa od samego jego udzielenia. Podjęcie decyzji o udzieleniu pełnomocnictwa do wyrażenia zgody, jak i decyzja co do osoby pełnomocnika, jest bez wątpienia „istotną sprawą dziecka" i rodzice powinni w tym przedmiocie rozstrzygać wspólnie. Natomiast już każdy z rodziców będzie mógł udzielić pełnomocnictwa do wyrażenia zgody ${ }^{39}$. Dziecko, którego rodzicom przysługuje władza rodzicielska, ma bowiem dwóch mogących samodzielnie działać przedstawicieli ustawowych ${ }^{40}$. Reguła ta jest określana jako „zasada dwu przedstawicieli dziecka” i zgodnie z nią każdy z rodziców może dokonywać w imieniu dziecka wszelkich czynności, nawet najbardziej ważkich ${ }^{41}$. Należy jednak podkreślić - abstrahując od poczynionych tutaj uwag - że możliwość udzielenia pełnomocnictwa na

${ }^{38}$ H. Haak, Władza rodzicielska. Komentarz, Torun 1995, s. 59.

39 Podobne rozwiązanie zostało przyjęte przez P. Bodył-Szymala odnośnie do zawarcia umowy rachunku bankowego dla małoletniego. Według autora każdy z przedstawicieli ustawowych jest umocowany do samodzielnego złożenia oświadczenia woli w imieniu dziecka, także w jego istotnych sprawach. Czym innym jest bowiem reprezentowanie dziecka $\mathrm{w}$ relacjach z osobami trzecimi, a czym innym podejmowanie merytorycznej decyzji co do tego, jakiej treści oświadczenie ma być składane w imieniu małoletniego. W określonych okolicznościach zawarcie umowy rachunku bankowego dla małoletniego może mieć charakter istotnej sprawy dziecka, co winno skłonić rodziców do osiągnięcia porozumienia w tej sprawie, natomiast uzgodnioną wolę rodziców w imieniu małoletniego może ważnie i skutecznie wyrazić każdy z przedstawicieli ustawowych. P. Bodył-Szymala, Małoletni posiadaczem rachunku bankowego, „Prawo Bankowe” 2004, nr 12, s. 77-78. Również B. Janiszewska, już odnośnie do zgody rodziców na zabieg medyczny stwierdza, że „z art. $97 \S 2$ k.r.o. wynika potrzeba wspólnego rozstrzygania przez rodziców, w wyniku którego dojdzie do uzyskania porozumienia w istotnych sprawach dziecka. Nie jest to sytuacja tożsama z koniecznością złożenia dwu oświadczeń, a ponadto - w formie pisemnej. Wystarczające wydaje się uzgodnienie stanowisk i złożenie oświadczenia przez jednego z przedstawicieli ustawowych (...)" (B. Janiszewska, Zgoda na udzielenie świadczenia zdrowotnego. Ujęcie wewnatrzsystemowe, Warszawa 2013, s. 514).

${ }^{40}$ K. Jagielski, Istota i treść władzy rodzicielskiej, „Studia Cywilistyczne” 1963, nr 3, s. 129.

${ }^{41}$ J. Ignatowicz, [w:] K. Pietrzykowski (red.), Kodeks rodzinny i opiekuńczy. Komentarz, Warszawa 2010, s. 881. 
zabieg medyczny powinna być wykorzystywana przede wszystkim gdy władza rodzicielska przysługuje z różnych względów jednemu z rodziców i siłą rzeczy skorzystanie z tej instytucji może okazać się nieuniknione.

Przeprowadzone rozważania pozwalają stwierdzić, że zajęte przez Sąd Najwyższy stanowisko jest co do zasady trafne. Uwzględnia bowiem dobro dziecka jako najważniejszy cel sprawowania władzy rodzicielskiej. Istotne jest jednak, aby możliwość udzielenia pełnomocnictwa do wyrażenia zgody była stosowana w sytuacjach zupełnie wyjątkowych, gdy rodzic rzeczywiście nie może takiej zgody wyrazić osobiście i w okolicznościach konkretnego wypadku jest to najlepszy sposób na zabezpieczenie dobra dziecka, a także przy wzięciu pod uwagę wszystkich wskazanych zastrzeżeń, wynikających zarówno z regulacji prawa cywilnego, jak i medycznego. Udzielenie analizowanego pełnomocnictwa powinno być więc traktowane jako swoistego rodzaju zło konieczne. Na negatywną ocenę zasługuje jednak fragmentaryczność uzasadnienia uchwały, szczególnie w kontekście licznych wątpliwości związanych z jej treścią a także ważkości podjętego w niej zagadnienia.

Słowa kluczowe: zgoda, zabieg medyczny, rodzice, władza rodzicielska, pełnomocnictwo

\section{Bibliografia}

Andrzejewski M., Prawo rodzinne i opiekuńcze, Warszawa 2010.

Bodył-Szymala P., Małoletni posiadaczem rachunku bankowego, „Prawo Bankowe" 2004, nr 12.

Cisek A., Ochrona dóbr osobistych osób sprawujących funkcje publiczne, „Acta Universitatis Wratislaviensis", No 3161, Prawo CCCVIII, 2009.

Dzienis P., Zgoda pacjenta jako warunek skuteczności leczenia, „Przegląd Sądowy" 2001, nr 11-12.

Filar M., Postępowanie lecznicze (świadczenie zdrowotne) w stosunku do pacjenta niezdolnego do wyrażenia zgody, „Prawo i Medycyna” 2003, nr 13.

Haak H., Władza rodzicielska. Komentarz, Toruń 1995.

Haberko J., Dziecko jako petnomocnik rodzica, Przegląd Sądowy 2013, nr 7-8.

Ignaczewski J. (red.), Wtadza rodzicielska i kontakty z dzieckiem. Komentarz, Warszawa 2012.

Ignatowicz J., Nazar M., Prawo rodzinne, Warszawa 2010.

Jagielski K., Istota i treść władzy rodzicielskiej, „Studia Cywilistyczne” 1963, nr 3. 
Janiszewska B., O udzieleniu petnomocnictwa medycznego - uwagi na tle uchwaty III CZP 19/15, „Monitor Prawniczy” 2015, nr 19.

Janiszewska B., Petnomocnictwo do wyrażenia zgody na udzielenie świadczenia zdrowotnego, "Monitor Prawniczy” 2015, nr 15.

Janiszewska B., Zgoda na udzielenie świadczenia zdrowotnego. Ujęcie wewnątrzsystemowe, Warszawa 2013.

Kędziora R., Problematyka zgody pacjenta w świetle polskiego ustawodawstwa medycznego, „Prokuratura i Prawo” 2003, nr 7-8.

Kidyba A. (red.), Kodeks cywilny. Komentarz LEX. Tom I. Część ogólna, Warszawa 2012.

Kubiak R., Prawo medyczne, Warszawa 2014.

Michałowska K., Charakter prawny i znaczenie zgody pacjenta na zabieg medyczny, Warszawa 2014.

Misztal-Konecka J., Wyłaczenie reprezentacji rodziców wobec dziecka pozostającego pod ich władza rodzicielska, "Przegląd Sądowy” 2010, nr 6.

Pietrzykowski K. (red.), Kodeks rodzinny i opiekuńczy. Komentarz, Warszawa 2010.

Pyziak-Szafnicka M., Księżak P. (red.), Kodeks cywilny. Komentarz. Część ogólna, LEX 2014.

Radwański Z., Olejniczak A., Prawo cywilne - część ogólna, Warszawa 2015.

Słyk J., Rozstrzyganie o istotnych sprawach dziecka w przypadku braku porozumienia rodziców, „Prawo w działaniu. Sprawy cywilne” 2013, nr 14.

Smyczyński T., Prawo rodzinne i opiekuńcze, Warszawa 2009.

Smyk M., Petnomocnictwo wedtug kodeksu cywilnego, Warszawa 2010.

Strzebińczyk J., Prawo rodzinne, Warszawa 2013.

Sylwestrzak A., Małoletni petnomocnik, „Przegląd Sądowy” 2012, nr 7-8.

Świderska M., Zgoda pacjenta na zabieg medyczny, Toruń 2007.

Wolter A., Ignatowicz J., Stefaniuk K., Prawo cywilne. Zarys części ogólnej, Warszawa 2001.

Zimna T., Glosa do uchwaty SN z dnia 13 maja 2015 r., III CZP 19/15, System Informacji Prawnej LEX.

\section{GLOSS ON SUPREME COURT RESOLUTION \\ OF 13 MAY 2015, III CZP 19/15, LEX 1679823}

\section{S u m m a r y}

The subject of the gloss is Supreme Court's Resolution of 13 May 2015 (III CZP 19/15). According to the resolution: "a legal representative of a minor may grant a power of attorney to submit a declaration of consent provided for in art. 34.3 of Medical Professions Act of 5 December 1996 (consolidated text: Dz. U. of 2015 item 464)". The Supreme Court declared absolutely inadmissible power of attorney to carry out parental authority. The Author is of the opinion that the presented resolution is to be approved. The Author anal- 
yses several specific issues, which were omitted by the Supreme Court, like requirements to be met by attorney or qualification of the power of attorney to important matters. According to the author power of attorney to submit a declaration of consent should be applied in completely exceptional situations, under taking into account objections arising from civil and medical law.

Key words: consent, medical treatment, parents, parental authority, power of attorney

\section{ГЛОССА К РЕЗОЯЮЦИИ ВЕРХОВНОГО СУДА С 13 МАЯ 2015 Г., ІІІ СZР 19/15, LEX 1679823}

\section{P e 3 ro m e}

Предметом гдоссы является резодюция Верховного Суда от 13 мая 2015 г. (III CZP 19/15), в которой Верховный Суд принял решение, что «законный представитель малолетнего ребенка может дать полномочия к составлению заявления о высказывании согласия, предусмотренного в ст. 34 п. 3 закона о профессии врача и зубного врача от 5 декабря 1996 г. (целостной текст: Официальный журнал от 2015 г. поз. 464)». Верховный Суд безусловно недопустимым признал предоставление через родителей общих полномочий к выполнению всех деятельностей из области родительской власти. Автор, одобряя относительно принципа занятия Верховным Судом положение, анадизирует связанные с ним некоторые вопросы, которые не взял во внимание Верховный Суд, сосредоточиваясь на требованиях, которые должно выполнять дицо, выполняющее функцию уполномоченного, а также для квалификации предоставления анализируемой доверенности, как важного дела ребенка. По мнению автора, предоставление доверенности к высказыванию согласия должно применяться в ситуациях, полностью искдючительных, с учитыванием предостережений, возникающих из гражданского и медицинского права.

Ключевые слова: согласие, медицинская процедура, родители, родительская власть, доверенность 